\title{
Article
}

\section{The Acquisition of Colistin Resistance Is Associated to the Amplification of a Large Chromosomal Region in Klebsiella pneumoniae kp52145}

\author{
María Blanca Sánchez ${ }^{\dagger}$, Alicia Sánchez-Gorostiaga, Trinidad Cuesta and José Luis Martínez *D \\ Departamento de Biotecnología Microbiana, Centro Nacional de Biotecnología, CSIC, Darwin 3, \\ Cantoblanco, 28049 Madrid, Spain; blanca.sanchez@imdea.org (M.B.S.); asanchez@cnb.csic.es (A.S.-G.); \\ tcuesta@cnb.csic.es (T.C.) \\ * Correspondence: jlmtnez@cnb.csic.es; Tel.: +34-5854542; Fax: +34-5854506 \\ + Current address: IMDEA Water Institute, Science and Technology Campus of the University of Alcalá, \\ Avenida Punto Com 2, 28805 Alcalá de Henares, Spain.
}

check for updates

Citation: Sánchez, M.B.; Sánchez-Gorostiaga, A.; Cuesta, T.; Martínez, J.L. The Acquisition of Colistin Resistance Is Associated to the Amplification of a Large Chromosomal Region in Klebsiella pneumoniae kp52145. Int. J. Mol. Sci. 2021, 22, 649. https://doi.org/ $10.3390 /$ ijms 22020649

Received: 18 November 2020 Accepted: 29 December 2020 Published: 11 January 2021

Publisher's Note: MDPI stays neutral with regard to jurisdictional clai$\mathrm{ms}$ in published maps and institutional affiliations.

Copyright: (C) 2021 by the authors. Licensee MDPI, Basel, Switzerland. This article is an open access article distributed under the terms and conditions of the Creative Commons Attribution (CC BY) license (https:// creativecommons.org/licenses/by/ $4.0 /)$.

\begin{abstract}
The appearance of carbapenem-resistant Klebsiella pneumoniae has increased the use of colistin as a last-resort antibiotic for treating infections by this pathogen. A consequence of its use has been the spread of colistin-resistant strains, in several cases carrying colistin resistance genes. In addition, when susceptible strains are confronted with colistin during treatment, mutation is a major cause of the acquisition of resistance. To analyze the mechanisms of resistance that might be selected during colistin treatment, an experimental evolution assay for 30 days using as a model the clinical K. pneumoniae kp52145 isolate in the presence of increasing amounts of colistin was performed. All evolved populations presented a decreased susceptibility to colistin, without showing cross-resistance to antibiotics belonging to other structural families. We did not find any common mutation in the evolved mutants, neither in already known genes, previously known to be associated with the resistance phenotype, nor in new ones. The only common genetic change observed in the strains that evolved in the presence of colistin was the amplification of a $34 \mathrm{~Kb}$ sequence, homologous to a prophage (Enterobacteria phage Fels-2). Our data support that gene amplification can be a driving force in the acquisition of colistin resistance by K. pneumoniae.
\end{abstract}

Keywords: Klebsiella pneumoniae; colistin resistance; gene amplification

\section{Introduction}

Polymyxins are polycationic peptides that were discovered in 1947 and used until the mid-1990s. However, the fact that they present some degree of nephrotoxicity and neurotoxicity made their use after those dates restricted to just a few types of infections [1,2]. Nevertheless, the increased prevalence of antibiotic-resistant Gram-negative pathogens and the lack of new antibiotics has led to a resurrection of antibiotics such as polymyxins, which are still useful, despite their side effects, when few other therapeutic options are available [3]. In this regard, polymyxins are active against relevant Gram-negative pathogens such as Pseudomonas aeruginosa, Acinetobacter baumannii, Klebsiella spp. and Escherichia coli, and other Enterobacterales [4].

The primary target of colistin (polymyxin E) is the lipopolysaccharide (LPS) of the outer membrane (OM) of Gram-negative bacteria. Colistin acts as a detergent-like compound, causing the displacement of $\mathrm{Ca}^{+2}$ and $\mathrm{Mg}^{+2}$ divalent cations from the phosphate groups of LPS that act as membrane stabilizers. This displacement increases membrane permeability and finally renders the disruption of the OM [5].

Bacteria employ several strategies to avoid colistin toxicity. The main resistance mechanisms known so far include modifications of lipid A with 4-amino-4-deoxy-L-arabinose (Ara4N) or phosphoethanolamine (PEtN), loss of LPS, formation of capsules and overexpression of efflux pumps or outer membrane proteins $[4,6,7]$. Although most of these 
resistance mechanisms involve the mutation of chromosomal genes, plasmid-encoded colistin resistance genes are particularly relevant. The main mobile colistin resistance gene is $m c r-1$. This gene, which encodes a phosphoethanolamine transferase, was firstly found in E. coli and K. pneumoniae plasmids in China [8,9] and is now present widespread [10]. More variants of the $m c r$ gene have emerged ( $m c r-2$ to $m c r-9)$, but $m c r-1$ remains the most prevalent one [11].

K. pneumoniae is a Gram-negative bacterial pathogen, which is a common cause of nosocomial infections and is included in the group of ESKAPE pathogens (acronym used to describe the following Gram-positive and Gram negative bacteria: Enterococcus faecium, Staphylococcus aureus, Klebsiella pneumoniae, Acinetobacter baumannii, Pseudomonas aeruginosa, and Enterobacter spp.) [12] due to their resistance to several antibiotics. Carbapenems have been used for the treatment of K. pneumoniae infections due to the increased prevalence of extended-spectrum-lactamases (ESBL)-producing isolates [10]. Nevertheless, carbapenemresistant K. pneumoniae (CR-KP) strains are also becoming widespread, making the use of other antibiotics, such as colistin, needed in the treatment of infections by resistant $K$. pneumoniae strains. The use of colistin for treating K. pneumonia infections has increased the selection of colistin resistant strains. Besides the aforementioned acquisition through horizontal gene transfer (HGT) of colistin resistance genes, in several cases, together with ESBLs, mutations in different genes have been identified in colistin-resistant K. pneumoniae strains. Modification of lipid $\mathrm{A}$ has been related with mutations in phoPQ, pmrAB, arnBCADTEF (also known as $p m r H F I J K L M$ ), $\operatorname{pmrD}, \operatorname{pmrC}, m g r B$ and $\operatorname{cr} A B$ [13-18], while mutations in $\operatorname{lp} x C, \operatorname{lp} x A$ and $\operatorname{lp} x D$ are associated with the loss of the LPS [19]. Inactivation of $m g r B$ has been found to be the most prevalent mutational colistin-resistance mechanism among those so far described $[20,21]$. Other mechanisms of resistance include changes in the capsule polysaccharide [22] and the overexpression of efflux pumps as AcrAB and KpnEF or the outer membrane protein $\mathrm{OprH}[7,23,24]$. The relevance of the different types of mutations may depend on the bacterial species involved. In this regard, it is worth mentioning that mutations in $l p x$ genes are more common in A. baumannii while mutations in phoPQ, pmr $A B$ and others are more common in Enterobacterales [11].

Molecular epidemiology of antibiotic resistance is based on the analysis of the already known antibiotic resistance genes/mutations. Experimental evolution approaches have been demonstrated to be valuable tools for analyzing the selection of genetic changes that may contribute to the emergence of antibiotic resistance, even before they are detected in clinical settings [25-30]. Among them, gene amplification is a phenomenon that has not been analyzed in detail. In the current work, using experimental evolution approaches, we detected that the amplification of a region of approximately $34 \mathrm{~Kb}$. of the K. pneumoniae genome seems to be responsible for the acquisition of reduced-colistin-susceptibility phenotype since no further common mutations in genes previously described to be involved in the acquisition of colistin resistance by bacterial pathogens were found in the evolved populations.

\section{Results}

\subsection{The Acquisition of Colistin Resistance Does Not Involve Cross-Resistance to Other Antibiotics}

The strain K. pneumoniae kp52145 [31], also known as CIP52.145 [32], belongs to the K. pneumoniae KpI group that includes the majority of strains associated with human infection, including several multidrug-resistant and hypervirulent clones [33]. It is then a good model for searching for novel potential mechanisms of antibiotic resistance. Towards this goal, K. pneumoniae kp52145 was submitted to experimental evolution under increasing concentrations of colistin as described in Methods. After 30 days of evolution in the presence (or absence, in control populations) of supra-inhibitory colistin concentrations, samples were subcultured without antibiotic to discard false or transient antibiotic resistance, and colistin Minimal Inhibitory Concentrations (MICs) were determined by double dilution. The MIC of the wild-type strain was $2 \mu \mathrm{g} / \mathrm{mL}$, while the MICs for the populations that evolved in the presence of colistin were $>512 \mu \mathrm{g} / \mathrm{mL}$ indicating that these populations had acquired colistin resistance. The antibiotic susceptibility to different antibiotics, in- 
cluding colistin, was analyzed in all evolved populations and in the wild-type strain using test-strips. Despite discrepancies between double dilution and test strips, which preclude the use of the latter to inform on clinically relevant antibiotic resistance [34]; test strips can be used in pairwise comparison of wild-type and mutant strains using an operational definition of resistance [35]. Further, it has been described that test strips usually define lower colistin MICs than double dilution in the case of K. pneumoniae [36]. Hence, the use of this technique may allow a better discrimination between the levels of colistin resistance as a function of the degree of amplification. Using this methodology, we confirmed that populations that have evolved without colistin showed a similar susceptibility phenotype than the wild-type strain, while the populations that evolved in presence of colistin were less susceptible to colistin than the wild-type strain (Table 1). None of the samples showed changes in susceptibility to other antibiotics besides colistin, suggesting that the genetic changes involved in the phenotype of resistance were specific for colistin.

Table 1. Minimal Inhibitory Concentrations (MICs) of different antibiotics for K. pneumoniae evolved in the presence or in absence of colistin.

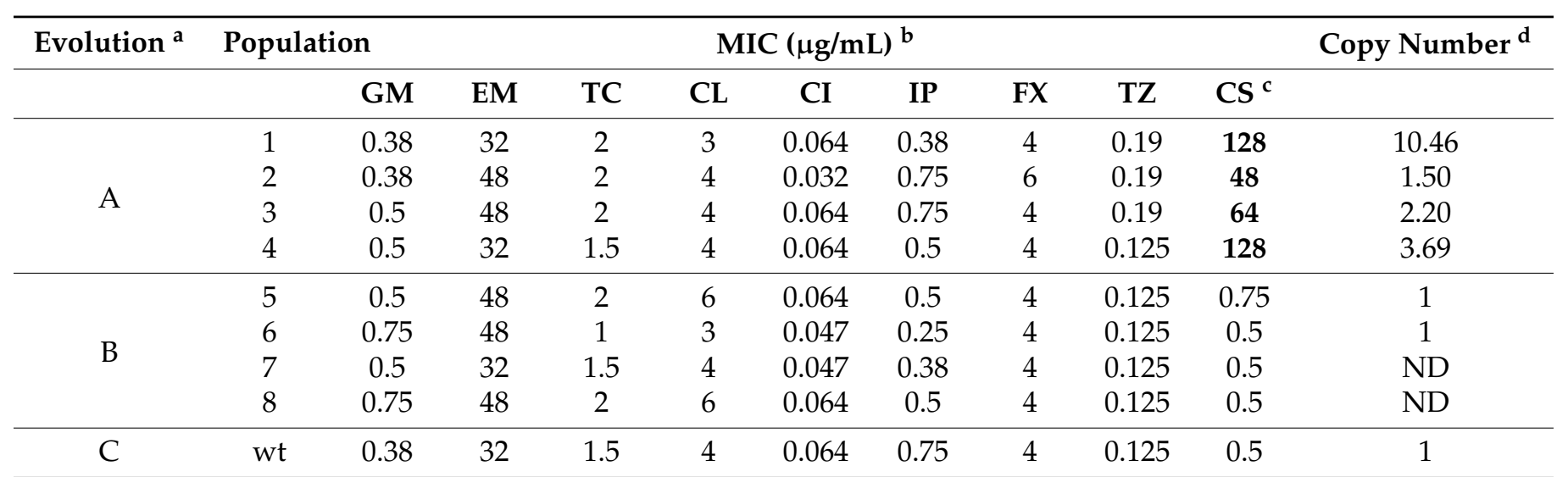

${ }^{a}$ Evolution condition in MH II. A, with 64 XMIC colistin; B, without colistin and C, wild-type K. pneumoniae kp52145 without evolution. b GM, gentamycin; EM, erythromycin; TC, tetracycline; CL, chloramphenicol; CI, ciprofloxacin; IP, imipenem; FX, cefoxitin and TZ, ceftazidime and CS, colistin. ${ }^{\mathrm{c}}$ In bold, MICs higher than the wild-type K. pneumoniae kp52145 without evolution. ${ }^{\mathrm{d}}$ corresponds to the fold-change in the copy number of the amplified region analyzed by real-time PCR. ND: not determined.

\subsection{Colistin Resistance Is Not Associated with Previously Described Resistance Mutations}

To analyze the genetic change(s) responsible for the colistin resistance phenotype, four populations that have evolved in the presence of the antibiotic, two control populations that have evolved in absence of antibiotics and the parental strain were re-sequenced, and these re-sequenced genomes were mapped against the already sequenced genome of their parental, wild-type strain. The presence of single nucleotide polymorphisms (SNPs), insertions and/or deletions (indels) is potentially responsible for the colistin resistance phenotype that was analyzed. Some mutations were found in both the control populations and in the populations challenged with colistin. These mutations are involved in the adaption for growing in the experimental conditions and were discarded from further analysis in the evolved mutants since they are not involved in colistin resistance. Data were filtered [37] by quality (probability that a given base is called correctly by the sequencer) and depth (number of reads covering any position), discarding any data with quality $<30$ and depth $<20$. By using these criteria, 11 possible SNPs were found. Among them, three synonymous substitutions, one conservative mutation, three missense mutations and four mutations localized in intergenic regions were found (Table 2). Seven of these mutations were found only in one evolved population, while four were found in two or more evolved populations. However, no common mutation was found in all evolved populations. Notably, in most cases (including all mutations present in more than one population), the mutations were located in a genomic region that was amplified in all the populations that had evolved in the presence of colistin (see below). 
Table 2. Mutations found in populations of K. pneumoniae kp52145 that have evolved in the presence of colistin.

\begin{tabular}{|c|c|c|c|c|c|c|c|c|}
\hline Position a & & utation & Type b & Population c & Quality & $\begin{array}{c}\text { Coverage } \\
(\%) d\end{array}$ & DP e & Product/Blast Homology \\
\hline 1852616 & $\mathrm{C}>\mathrm{T}$ & Arg76Cys & MSM & 3 & 225 & 68.97 & 29 & $\begin{array}{l}\text { Succinate dehydrogenase } \\
\text { cytochrome b556 subunit }\end{array}$ \\
\hline 2011786 & $\mathrm{C}>\mathrm{T}$ & intergenic_region & IR & 1 & 225 & 66.66 & 84 & $\begin{array}{l}3^{\prime} \text { tyrosine-type } \\
\text { recombinase/integrase }\end{array}$ \\
\hline 2014814 & $\mathrm{C}>\mathrm{A}$ & Leu48Leu & SS & $\begin{array}{l}1 \\
3 \\
4\end{array}$ & $\begin{array}{l}222 \\
225 \\
213\end{array}$ & $\begin{array}{l}90.42 \\
56.25 \\
27.27\end{array}$ & $\begin{array}{l}355 \\
51 \\
99\end{array}$ & Phage repressor protein CI \\
\hline 2014977 & $\mathrm{~T}>\mathrm{C}$ & $\begin{array}{l}\text { intergenic } \\
\text { region }\end{array}$ & IR & $\begin{array}{l}1 \\
4\end{array}$ & $\begin{array}{l}222 \\
225\end{array}$ & $\begin{array}{l}89.23 \\
74.58\end{array}$ & $\begin{array}{l}362 \\
118\end{array}$ & $5^{\prime}$ Phage repressor protein $\mathrm{CI}$ \\
\hline 2015036 & $A>G$ & $\begin{array}{l}\text { intergenic } \\
\text { region }\end{array}$ & IR & 3 & 225 & 59.52 & 42 & $5^{\prime}$ Regulator \\
\hline 2015480 & $G>A$ & Asp61Asn & MSM & 3 & 225 & 51.90 & 80 & Phage regulatory protein $\mathrm{CII}$ \\
\hline 2037216 & $\mathrm{~T}>\mathrm{C}$ & Val505Ala & $\mathrm{CM}$ & $\begin{array}{l}3 \\
4\end{array}$ & $\begin{array}{l}225 \\
225\end{array}$ & $\begin{array}{l}37.87 \\
67.57\end{array}$ & $\begin{array}{l}66 \\
111\end{array}$ & Phage tail protein \\
\hline 2043437 & $\mathrm{C}>\mathrm{T}$ & Ala715Ala & SS & $\begin{array}{l}3 \\
4\end{array}$ & $\begin{array}{l}225 \\
225\end{array}$ & $\begin{array}{l}53.57 \\
73.74 \\
\end{array}$ & $\begin{array}{l}56 \\
99\end{array}$ & Phage tail tape measure protein \\
\hline 2045994 & $\mathrm{C}>\mathrm{T}$ & $\begin{array}{l}\text { intergenic } \\
\text { region }\end{array}$ & IR & 1 & 222 & 89.71 & 418 & $\begin{array}{l}5^{\prime} \text { transcriptional } \\
\text { activator Ogr/delta }\end{array}$ \\
\hline 3994455 & $A>C$ & Val502Gly & MSM & 2 & 152 & 40.9 & 22 & $\begin{array}{l}\text { PTS beta-glucoside transporter } \\
\text { subunit IIABC }\end{array}$ \\
\hline 5429220 & $\mathrm{C}>\mathrm{T}$ & Glu601Glu & SS & 1 & 222 & 97.5 & 40 & DEAD/DEAH box helicase \\
\hline
\end{tabular}

Of the three missense mutations, one was localized in the gene encoding the succinate dehydrogenase cytochrome b 556 subunit, and the prediction of the effect, analyzed with PROVEAN, was neutral (-0.727/Arg76Cys). The other two missense mutations were predicted to have a deleterious effect; one was localized in a gene encoding the phage regulatory protein CII (-4.135/Asp61Asn) and the other in a gene encoding the PTS beta-glucoside transporter subunit IIABC ( -5.264 /Val502Gly). However, both deleterious missense mutations showed a low number of reads containing them (low depth) and also a low coverage (Table 2), indicating they were not predominant in the studied populations. None of these mutations was present in any of the genes described so far in other works to be involved in the acquisition of colistin resistance.

\subsection{Chromosomal Amplifications Are Associated with Colistin Resistance}

It has been described that unstable tandem gene amplification generates heteroresistance to colistin in Salmonella typhimurium [38]. To address if genomic amplifications may be involved in the phenotype of colistin resistance in the evolved populations, we analyzed the sequenced genomes using the CNV-seq tool [39]. Some regions showed an increased number of reads of the genome in the wild-type strain and in all studied populations, controls included, indicating that they are present in more than one copy in the genome of K. pneumoniae kp52145. Hence, the increased copy numbers of those regions were not selected under colistin challenge, and they were not further analyzed. In addition to these common regions, a chromosomal amplification of 34,569 bp containing 48 coding sequences (CDS) was identified in the four populations that had evolved in presence of colistin, while this region was not amplified in the populations that had evolved in the absence of antibiotic challenge (Figure 1). To further confirm that this region was amplified in the evolved populations, its copy number was estimated by real-time PCR comparing the amount of two genes, one inside (BN49-RS11300) and another outside $(r p o B)$ the putatively amplified region. Statistically significant $(p<0.05)$ differences ranging from 11 copies to 1.5 copies were found in the studied populations (Figure 2), confirming that the amplification of this region is linked to colistin resistance in the studied evolved 
populations. To further support that the region is amplified, the copy numbers of the genes BN49_RS28910, BN49_RS11385 and BN49_RS11425 were also estimated. In all cases, amplification was detected in all populations, and the observed trend in the level of amplification was the same: $1>4>3>2$. Notably, those populations presenting higher copy numbers of the amplified region also display higher colistin MICs (Table 1). This result, together with the absence of any other relevant genetic change, supports that the genetic cause of colistin resistance is the amplification of this genomic region. Four hypothetical proteins, 30 phage-related genes, three domain-containing proteins with unknown function and 11 genes encoding proteins presenting different functions (Figure 3 and Table 3 ) were identified in this region. Several of the genes present in this region were related to DNA metabolism, three to DNA mobility (integrase, IS1 family transposase and DNA invertase) and five to transcription and replication (RNA polymerase-binding protein DksA, DNA adenine methylase, replication endonuclease, DinI family protein and levan regulatory domain protein).

Table 3. Genes identified in the over-represented sequence.

\begin{tabular}{|c|c|c|c|c|c|c|}
\hline \multirow{2}{*}{ Number ${ }^{a}$} & \multirow{2}{*}{ Locus } & \multicolumn{2}{|c|}{ Position } & \multirow{2}{*}{ Strand } & \multirow{2}{*}{ Size (bp) } & \multirow{2}{*}{ Product/Blast Homology } \\
\hline & & First & End & & & \\
\hline 1 & BN49_RS11210 & 2011880 & 2012932 & - & 1053 & Tyrosine-type recombinase/integrase \\
\hline 2 & BN49_RS11215 & 2013019 & 2014008 & - & 990 & Hypothetical protein \\
\hline 3 & BN49_RS28910 & 2014019 & 2014957 & - & 939 & Phage repressor protein CI \\
\hline 4 & BN49_RS28915 & 2015046 & 2015267 & + & 222 & Putative uncharacterized protein ORFA in retron EC67 \\
\hline 5 & BN49 RS11225 & 2015300 & 2015809 & + & 510 & (E. coli)/ Regulator (E. coli, K. pneumoniae) \\
\hline 6 & BN49 RS11230 & 2015817 & 2016017 & + & 201 & $\begin{array}{l}\text { Phage regulatory protein CII } \\
\text { DUF2724 domain-containing protein }\end{array}$ \\
\hline 7 & BN49 RS11235 & 2015981 & 2016322 & + & 342 & $\begin{array}{l}\text { DUF2/24 domain-containing protein } \\
\text { DUF5347 domain-containing protein }\end{array}$ \\
\hline 8 & BN49 RS11240 & 2016390 & 2016623 & + & 234 & $\begin{array}{l}\text { DUF5347 domain-containing protein } \\
\text { DUF2732 domain-containing protein }\end{array}$ \\
\hline 9 & BN49 RS11245 & 2016623 & 2016850 & + & 228 & TraR/DksA family transcriptional regulator \\
\hline 10 & BN49 RS11250 & 2016847 & 2017704 & + & 858 & $\begin{array}{l}\text { TraR/DKsA family transcriptional regulator } \\
\text { DNA adenine methylase }\end{array}$ \\
\hline 11 & BN49 RS11255 & 2017701 & 2020115 & + & 2415 & $\begin{array}{l}\text { DNA adenine methylase } \\
\text { Replication endonuclease }\end{array}$ \\
\hline 12 & BN49 RS11260 & 2020269 & 2020457 & + & 189 & $\begin{array}{l}\text { Replication endonuclease } \\
\text { levan regullatory domain protein }\end{array}$ \\
\hline 13 & BN49 RS11265 & 2020468 & 2020701 & + & 234 & levan regulatory domain protein \\
\hline & BN49 RS11270 & 2020988 & 2021206 & +1 & & \\
\hline & & 2020900 & & & 219 & Multidrug ABC transporter ATPase (E. coli) \\
\hline & & 2021206 & 2022048 & + & 843 & Hypothetical protein \\
\hline 17 & BN49_RS11280 & 2022058 & 2022267 & + & 210 & Hypothetical protein \\
\hline 18 & BN49_RS11285 & 2022264 & 2023697 & + & 1434 & SEFIR domain-containing protein \\
\hline 19 & BN49_RS11290 & 2023732 & 2024772 & - & 1041 & Phage portal protein \\
\hline & BN49_RS11295 & 2024769 & 2025494 & - & 726 & Terminase-like family protein \\
\hline 20 & BN49_RS11300 & 2025494 & 2027260 & - & 1767 & Terminase ATPase subunit \\
\hline $\begin{array}{l}21 \\
22\end{array}$ & BN49_RS11305 & 2027403 & 2028236 & + & 834 & Phage capsid protein \\
\hline $\begin{array}{l}22 \\
23\end{array}$ & BN49_RS11310 & 2028253 & 2029311 & + & 1059 & Phage major capsid protein, P2 family \\
\hline 23 & BN49_RS11315 & 2029315 & 2029965 & + & 651 & Terminase endonuclease subunit \\
\hline 24 & BN49_RS11320 & 2030061 & 2030525 & + & 465 & Head completion/stabilization protein \\
\hline 25 & BN49_RS11325 & 2030525 & 2030728 & + & 204 & Tail protein $X$ \\
\hline 26 & BN49_RS11330 & 2030732 & 2030947 & + & 216 & Membrane protein (Enterobacteriaceae) \\
\hline 27 & BN49_RS11335 & 2030967 & 2031440 & + & 513 & Lysozyme \\
\hline 28 & BN49_RS11340 & 2031442 & 2031819 & + & 378 & Hypothetical protein \\
\hline 29 & BN49_RS11345 & 2031816 & 2032244 & + & 429 & LysB family phage lysis regulatory protein \\
\hline 30 & BN49_RS11355 & 2032319 & 2032771 & + & 453 & Tail completion protein $\mathrm{R}$ \\
\hline 31 & BN49_RS11360 & 2032764 & 2033210 & + & 447 & Phage virion morphogenesis protein \\
\hline 32 & BN49_RS11365 & 2033279 & 2033857 & + & 579 & Phage baseplate assembly protein $\mathrm{V}$ \\
\hline 33 & BN49_RS11370 & 2033854 & 2034213 & + & 360 & Baseplate assembly protein \\
\hline 34 & BN49_RS11375 & 2034200 & 2035108 & + & 909 & Baseplate assembly protein \\
\hline 35 & BN49_RS11380 & 2035101 & 2035706 & + & 606 & Phage tail protein I \\
\hline 36 & BN49_RS11385 & 2035703 & 2037424 & + & 1722 & Tail fiber protein/phage tail protein \\
\hline 37 & BN49_RS11390 & 2037424 & 2037606 & + & 183 & Phage tail protein \\
\hline 38 & BN49_RS28920 & 2037587 & 2037739 & - & 153 & Tail fiber assembly protein \\
\hline 39 & BN49_RS11395 & 2037760 & 2038207 & - & 448 & IS1 family transposase (Pseudo: partial start) \\
\hline 40 & BN49 RS11400 & 2038403 & 2038969 & + & 567 & DDE_Tnp_IS1 superfamily \\
\hline 41 & BN49 RS11405 & 2039112 & $\begin{array}{l}2030909 \\
2040284\end{array}$ & $\begin{array}{l}+ \\
+\end{array}$ & 1173 & $\begin{array}{l}\text { DNA invertase } \\
\text { Maior tail sheath protein }\end{array}$ \\
\hline 42 & BN49_RS11410 & 2040294 & 2040809 & + & 516 & $\begin{array}{l}\text { Major tall sheath protein } \\
\text { Phage major tail tube protein }\end{array}$ \\
\hline 43 & BN49_RS11415 & 2040864 & 2041166 & + & 303 & Phage tail assembly protein \\
\hline 44 & BN49_RS11420 & 2041181 & 2041300 & + & 120 & GpE family phage tail protein \\
\hline 45 & BN49_RS11425 & 2041293 & 2044370 & + & 3078 & Phage tail tape measure protein \\
\hline 46 & BN49_RS11430 & 2044367 & 2044852 & + & 486 & Bacteriophage tail protein \\
\hline 47 & BN49_RS11435 & 2044849 & 2045949 & + & 1101 & Phage late control D family protein \\
\hline 48 & BN49_RS28925 & 2046040 & 2046258 & + & 219 & Transcriptional activator Ogr/delta \\
\hline
\end{tabular}




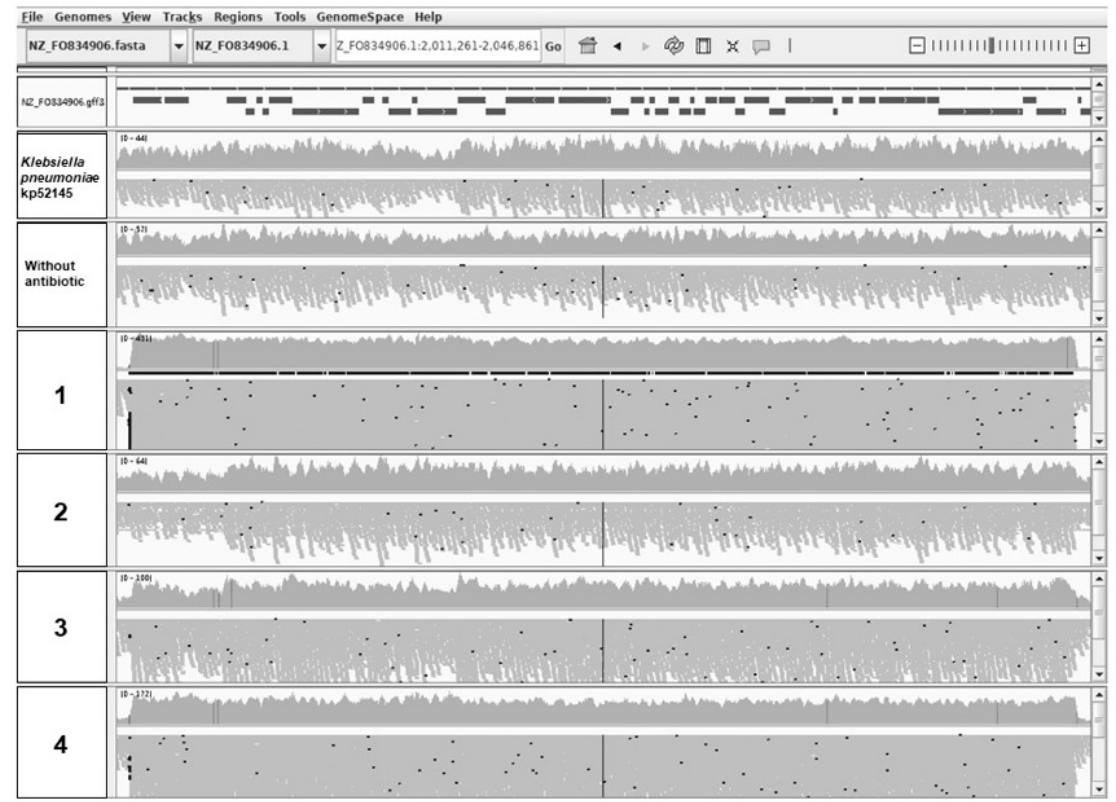

Figure 1. Image of the reads of the putatively amplified region obtained using Integrated Genome Viewer (IGV). An increased number of reads, mainly in populations 1, 3 and 4, which correspond with MICs of 128, 64 and $128 \mu \mathrm{g} / \mathrm{mL}$, was observed.

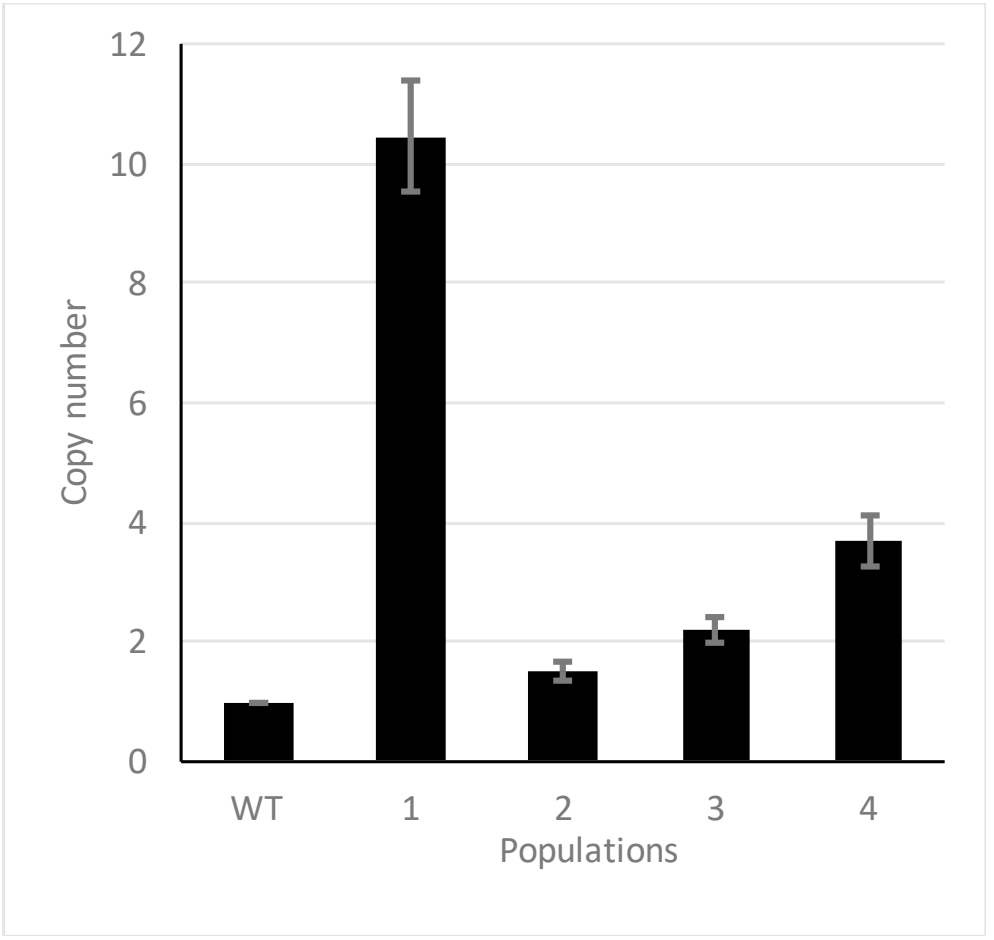

Figure 2. Analysis of the copy number of the amplified region by real-time PCR. Copy number of the amplified region was estimated measuring the amount of BN49-RS11300 present in each population and considering that the wild-type strain presents one copy of the gene. The figure shows the average and standard deviation of copy numbers for each of the populations. In all cases, the differences were statistically significant $(p<0.05)$. 


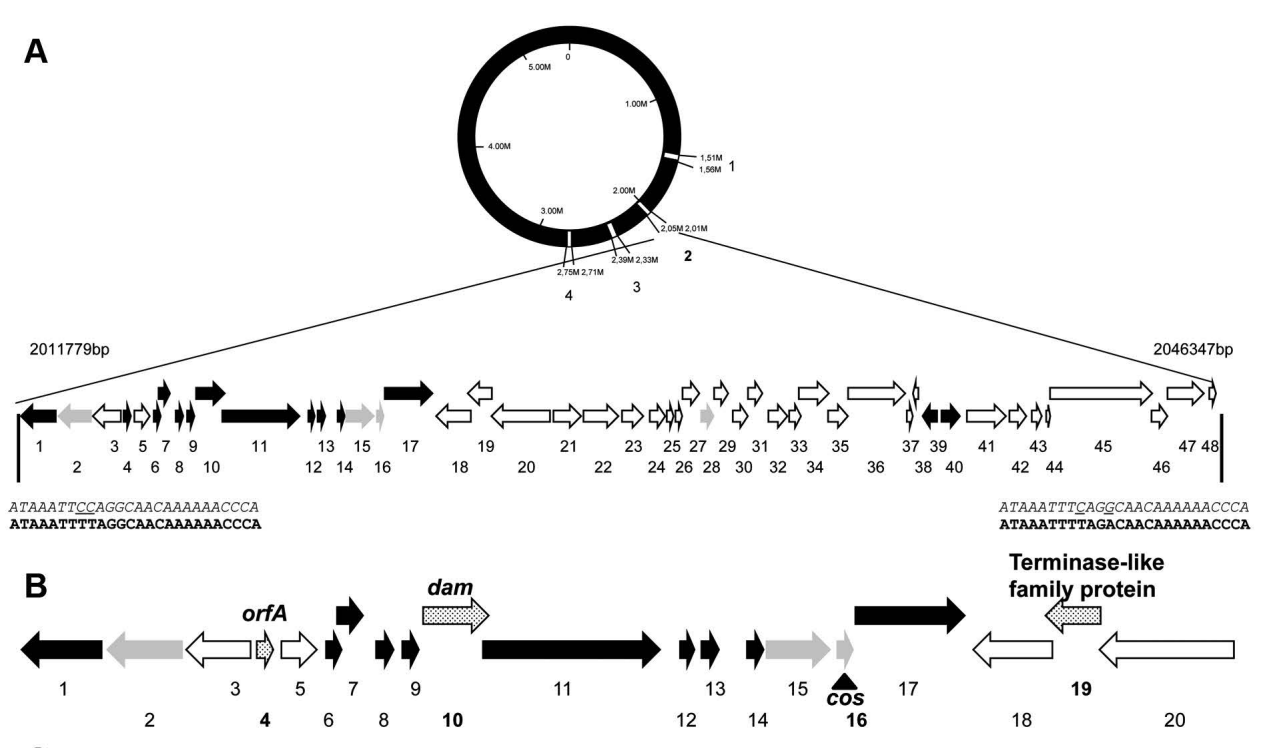

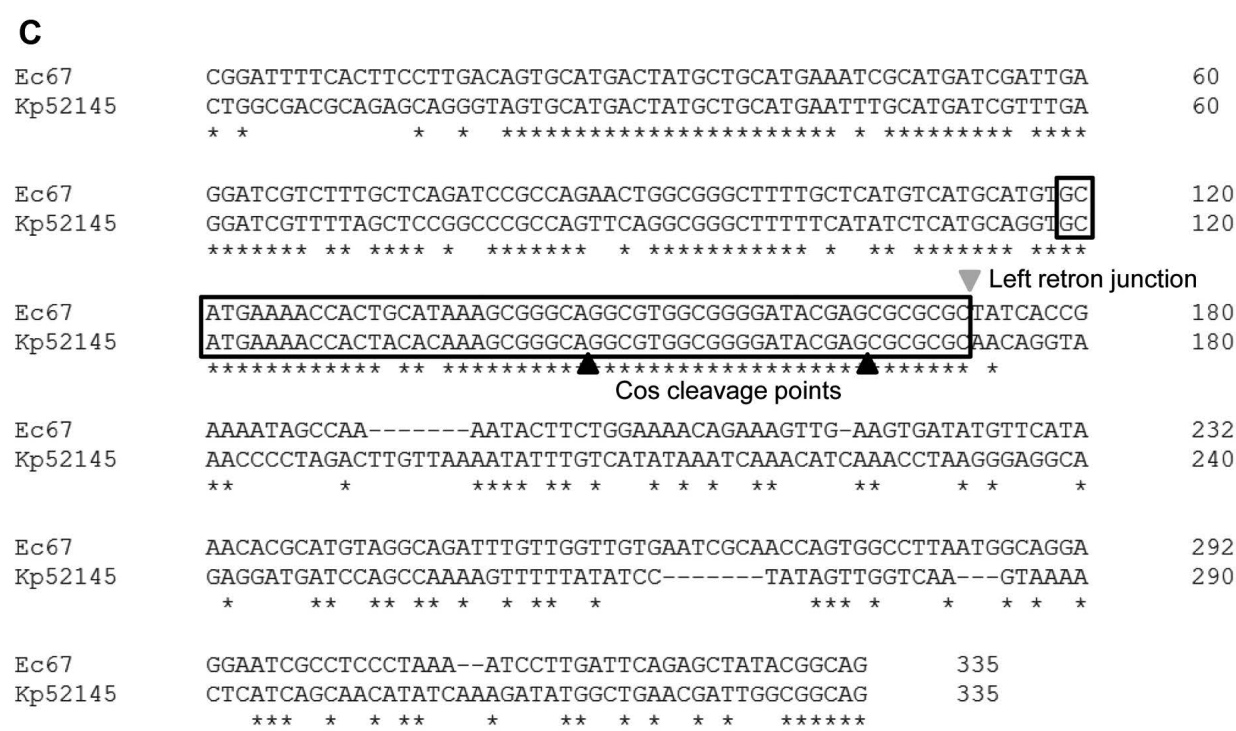

Figure 3. Region in the K. pneumoniae chromosome, and genes identified within, that is over-represented in populations that have evolved in presence of colistin. Panel B shows the localization of the other four prophages identified in K. pneumoniae kp52145. Panel A shows the genetic structure of the $34569 \mathrm{bp}$ amplified region, correspondent to prophage 2. Arrows show the orientation of predicted open reading frames ORF. Hypothetical proteins (grey arrows), phage-related proteins (white arrows) and other functions (black arrows). Numbers under arrows are correlated with numbers in Table 3. The figure also shows the $26 \mathrm{bp}$ direct repeats flanking this genomic region sequence. In bold, the sequences present in E. coli; in italics, $\mathrm{K}$. pneumoniae sequences. The nucleotides that differ between both microorganisms are underlined. Panel $\mathrm{B}$ shows the genomic region containing genes identified as related with retron Ec67; orf A, dam and Terminase-like family protein (dotted arrows), and the position of $\cos$ sequence (black triangle). C, alignment of conservative cos site (boxed) and cos cleavage points (black triangles) and retron junction (grey triangle) of Ec67 and K. pneumoniae kp52145 (Clustal OMEGA [40].

Two genes encoded proteins analogous to transporters: a membrane protein and a multidrug ABC transporter ATPase. The membrane protein possesses a domain belonging to Phage_holin_2_3 superfamily. This family includes small hydrophobic phage proteins called holins with one transmembrane domain. This gene was followed by another gene homologous to lysozyme, a genomic arrangement (holin-lysozyme) that has been described previously in a phage [41]. The gene encoding the putative lysozyme contains a phage lysozyme domain, whose family includes lambda phage lysozymes and E. coli endolysins [42]. Concerning the putative ATPase of an ABC transporter, it contains a protein-protein interaction domain (SEFIR domain-containing protein), which has been 
associated to transmembrane receptors and soluble factors with eukaryotic origin and with unknown functions [43].

One gene was homologous to orf $A$, which encodes a putative protein present in retron EC67 of E. coli [44]. The retron Ec67 is found in a $34 \mathrm{~kb}$ sequence flanked by direct repeats of a $26 \mathrm{bp}$ and contains, among other genes, an orf encoding a Dam DNA methylase [44]. Notably, the sequence amplified in the evolved K. pneumoniae Kp52145 populations that had evolved in the presence of antibiotics displays similar direct repeats of a $26 \mathrm{bp}$ flanking the amplified sequence (Figure 3), and a gene identified as a DNA adenine methylase was present inside.

It has been described that retron Ec67 is inserted into a prophage between cos sequence and the DNA packaging gene [45]. A similar genetic structure, with a cos sequence in the left side and a terminase-like family protein, was found in the $34 \mathrm{~Kb}$ amplified sequence (Figure 3).

The identification of a large number of phage-related genes suggests that this region could be a prophage. The analysis of the complete genome of K. pneumoniae kp52145, using the webserver PHASTER, showed the presence of four prophages (Table 4, Supplementary Table S1). One of them, the Enterobacteriaceae phage Fels-2 [46], corresponds to the sequence that is amplified upon colistin challenge. Blast search of NCBI database (20 December 2020) showed that this phage has been detected in 98 Enterobacterales. Among them, the highest prevalence was for Klebsiella pneumoniae with 43 hits followed by Salmonella enterica subs. enterica serovar Typhi with 39 hits.

Table 4. Localization of the prophages identified in the genome of K. pneumoniae kp52145. Number 2 corresponds with the over-represented region in evolved mutants.

\begin{tabular}{cccc}
\hline & Region Length & Genome Position & Condition $^{\text {a }}$ \\
\hline 1 & $50 \mathrm{~kb}$ & $1506010-1556027$ & intact \\
2 & $34.5 \mathrm{~kb}$ & $2011787-2046330$ & intact \\
3 & $33.1 \mathrm{~kb}$ & $2346519-2379687$ & intact \\
4 & $50.6 \mathrm{~kb}$ & $2700266-2750911$ & intact \\
\hline
\end{tabular}

${ }^{a}$ Prediction if the prophage is intact or incomplete.

\section{Discussion}

The spread of carbapenemase-producing Enterobacteriaceae has increased the use of colistin for treating infections by these organisms. This is the case of K. pneumoniae, where resistance to carbapenems is a relevant problem [47], making the use of other antibiotics, such as colistin, tigecycline or aminoglycosides, a clear need. Nevertheless, the use of these antibiotics is also selecting resistance to them. In the case of colistin, the acquisition of $\mathrm{mcr}$ is a main element in the development of resistance [10]. Nevertheless, genetic modifications, selected in presence of colistin, in the treated patient, may also contribute to such resistance $[9,17]$. To ascertain those potential modifications, we performed experimental evolution assays for 30 days in the presence of increasing amounts of colistin of the clinical K. pneumoniae strain kp52145 (serotype O1:K2) [31]. Notably, genomic analysis of the evolved populations showed that they do not present any of the mutations previously described to be associated with colistin resistance in other pathogens, such as those present in $m g r B$, phoPQ, $p m r C A B$, and $\operatorname{cr} A B[9,17]$. The only common modification found in the populations that have evolved in the presence of colistin was the amplification of a 34-kb genomic region, which mainly contains phages' genes. Increased colistin resistance in Salmonella typhimurium due to amplification has been described, but in this case, the amplified region included the gene $p m r D$, a positive regulator of the expression of genes that modify lipid A [38]. The facts that amplification is the only genetic modification found, that it is present in all evolved populations and that the populations presenting higher copy numbers are also the ones with higher colistin MICs support that the genetic cause of acquiring colistin resistance is the amplification of this genomic region. However, the 
biochemical basis of colistin resistance due to the amplification of this region remains elusive. As above stated, the amplified region seems to be a prophage. Some of the genes present in this region are related to transport (membrane protein and multidrug $A B C$ transporter ATPase), a feature that might be linked to the observed resistance phenotype, while another one is annotated as DNA adenine methylase, whose expression may modify antibiotic resistance. Nevertheless, the potential association of the amplification of these genes with colistin resistance remains a speculation.

Antibiotic resistance has been associated with the presence of prophages in some cases. In some cases, this is due to the presence of known resistance genes inside the phage genome [48]. However, there are also examples where the presence of cryptic prophages, not containing known antibiotic resistance genes, has been associated with antibiotic resistance, although the mechanisms involved are largely ignored [49]. A similar situation might be occurring in the present study. Although the molecular bases of resistance are not known yet, our results support that gene amplification can be involved in the acquisition of colistin resistance in K. pneumoniae and that retrons and prophages might play a role in this phenotype. Most studies on the genetic basis of antibiotic resistance focus on the acquisition of resistance genes and the selection of mutations. Together with previously published works, our study shows that gene amplification in general and of that of prophages in particular might also play a role in antibiotic resistance that, with some exceptions, is still underestimated [50].

\section{Materials and Methods}

\subsection{Strain and Culture Medium}

The clinical strain K. pneumoniae kp52145 (serotype O1:K2) [31], whose sequence is available at https:/ / www.ncbi.nlm.nih.gov/nuccore/ (Reference Sequence: chromosome NZ_FO834906.1; plasmid II, NZ_FO834905.1; plasmid I, NZ_FO834904.1) [51,52], was used for the studies. Bacteria were grown in Mueller Hinton (MH) or Mueller Hinton II (MH II) liquid or agar plates [53] at $37^{\circ} \mathrm{C}$.

\subsection{Antibiotic Susceptibility}

The colistin MICs of the wild-type K. pneumoniae kp52145 strains and the evolved populations were determined by double dilution following CLSI rules [54]. The susceptibility phenotype of the evolved K. pneumoniae strains was determined as well using Minimal Inhibitory Concentration (MIC) test strips (Liofilchem) in MH II (for colistin) or MH (for gentamycin, erythromycin, tetracycline, chloramphenicol, ciprofloxacin, imipenem, cefoxitin and ceftazidime) agar plates. The conditions for the assay were those recommended by CLSI for disk-diffusion assays [36].

\subsection{Colistin Evolution Assay}

An experimental evolution assay using inhibitory concentrations of colistin in MH II was performed following protocols common in this type of assays [25-30]. Previous work had shown that $2 \mu \mathrm{g} / \mathrm{mL}$ polymyxin killed half of the K. pneumoniae kp52145 population in one hour [55]. Futhermore, we determined that the same concentration of colistin inhibited K. pneumoniae kp52145 growth in our experimental conditions. Hence, this concentration was chosen as the starting point in our assays. The evolution was made in quadruplicate. Four different isolated colonies were independently suspended in $1 \mathrm{~mL} \mathrm{NaCl} 0.85 \%$ each Each suspension was used to inoculate $2 \mathrm{~mL} \mathrm{MH} \mathrm{II,} \mathrm{with} \mathrm{or} \mathrm{without} 2 \mu \mathrm{g} / \mathrm{mL}$ colistin (MIC), with approximately $10^{3} \mathrm{CFU} / \mathrm{mL}$ each. A total of eight cultures (four with and four without colistin) were then performed. Cultures were grown at $37^{\circ} \mathrm{C}$ and 180 r.p.m. Every $24 \mathrm{~h}, 2 \mu \mathrm{L}$ of overnight cultures were used to inoculate new $2 \mathrm{~mL}$ MH II at a 1:1000 dilution. This step was repeated for 30 days, increasing the concentration of colistin twofold every five days, with the experiment ending when colistin concentrations reached 64X MIC. Four control cultures were grown in parallel, under the same conditions, but in the absence of colistin. At the end of the evolution assay, the evolved populations were further 
subcultured (three sequential passages) without antibiotic before analyzing the antibiotic resistance phenotype to avoid the possibility of transient induction of resistance.

\subsection{Genomic DNA Extraction and Re-Sequencing of the Evolved Populations}

Genomic DNA of each evolved sample was obtained from $4 \mathrm{~mL}$ of an overnight culture using the G NOME ${ }^{\circledR}$ DNA isolation kit (MP Biomedicals) The quality and quantity of the DNA was determined by agarose gel electrophoresis and by using a NanoDrop spectrophotometer, respectively. The genomes of the wild type strain, two controls (populations 5,6), and four evolved samples (populations 1-4) were re-sequenced at the Unidad de Genómica Antonia Martín Gallardo, Parque Científico de Madrid, Spain. To that goal, TruSeq DNA PCR-free Prep (Illumina) based libraries from $5 \mu \mathrm{g}$ of DNA were obtained and sequenced using MySeq Illumina technology in a single-end 1X150 format. The numbers of reads were: wild type, 1107220; population 1, 1341078; population 2, 1008802; population 3, 1276618; population 4, 1104682; population 5, 1332846; population 6, 1247129 . The coverage of each sample was in the $24-45 X$ range.

\subsection{Bioinformatic Analysis}

Sequences were aligned against the genome of the wild-type strain K. pneumoniae strain kp52145 deposited at NCBI (https:/ / www.ncbi.nlm.nih.gov/nuccore/; GenBank: FO834906.1). To identify the presence of Single Nucleotide Polymorphisms (SNPs), the programs Bowtie2 [56], SAMtools [57,58], SnpEff [59] and bedtools [60] were used. Quality and depth filters were made with SnpSift [37]. For the search of over-represented sequences, the CNV-seq program [39] was used. Results were visualized using the Integrated Genome Viewer (IGV, Broad institute, http:/ / software.broadinstitute.org/software/igv/). The effect of missense mutations was predicted with the program PROVEAN [61]. Scores $\leq-2.5$ are predicted to have a deleterious effect, while scores $>-2.5$ are predicted to have a neutral effect.

The genes localized in the over-represented region were identified using the information available for the reference sequence of K. pneumoniae kp52145 (see above) and by homology with other proteins using Blastx (https:/ / blast.ncbi.nlm.nih.gov/Blast.cgi). The alignment of sequences was performed with Clustal OMEGA [40]

The PHAge Search Tool Enhanced Release (https://phaster.ca/) was used to search for prophages in K. pneumonia genome [62,63].

\subsection{Real-Time PCR}

Real-time PCR reactions were prepared using $0.25 \mathrm{ng}$ from the genomic DNA obtained as described above. Primers for rpoB reference gene or BN49-RS11300, BN49-RS28910, BN49-RS11385 and BN49-RS11425 genes present in the K. pneumoniae kp52145 amplified genomic region were used at $10 \mathrm{nM}$ (Table 5). Finally, $10 \mu \mathrm{L}$ of Power SYBR Green PCR Master Mix (Applied Biosystems, Woolston, Warrington, UK) was added to the mixture. The reaction efficiency for each primer set was estimated on a series of DNA dilutions. Reactions were run on a 7500 Real-Time PCR System (Applied Biosystems, Woolston, Warrington, UK) with the following protocol: $2 \mathrm{~min}$ at $50{ }^{\circ} \mathrm{C} ; 10 \mathrm{~s}$ at $95^{\circ} \mathrm{C} ; 40$ cycles of $10 \mathrm{~s}$ at $95{ }^{\circ} \mathrm{C}$; $1 \mathrm{~min}$ at $60^{\circ} \mathrm{C}$, followed by a melting curve generated from $60{ }^{\circ} \mathrm{C}$ to $95^{\circ} \mathrm{C}$. Ten replicates were performed, and the fold change of BN49-RS11300 copy number was estimated using the $2^{-\Delta \Delta \mathrm{Ct}}$ method [64]. The number of copies was estimated as the average of the different determinations. The statistical significance of the results was estimated by $t$-test. 
Table 5. Sequences of the primers used for qPCR.

\begin{tabular}{|c|c|}
\hline Name & Sequence $\left(5^{\prime}-3^{\prime}\right)$ \\
\hline RpoB-fwd & GATCCGTGGCGTGACTTATT \\
\hline RpoB-rev & GCCCATGTAGACTTCTTGTTCT \\
\hline RS11300-fwd & CAGGCCATGCTGCTGTACTT \\
\hline RS11300-rev & GTCCAGCGGCCCATAGT \\
\hline RS28910-fwd & CCTTCTGCGGTAACTCCAATAG \\
\hline RS28910-rev & CAGCTCTGTAGCCCAACTTAAA \\
\hline RS11385-fwd & CTAGCTCAGTTGGTTCGTTTATTTC \\
\hline RS11385-rev & GTCGGGCTATCGCTGTTATT \\
\hline RS11425-fwd & GGAGGTGCGTGATCGTATTG \\
\hline RS11425-rev & GGCATCTTCCATGCTGGTATAG \\
\hline
\end{tabular}

Supplementary Materials: The following are available online at https: / www.mdpi.com/1422-0 067/22/2/649/s1, Table S1: Data obtained from the PHAge Search Tool Enhanced Release of the present prophage sequence regions in K. pneumoniae kp52145.

Author Contributions: Conceptualization, J.L.M. and M.B.S.; investigation, M.B.S., A.S.-G. and T.C.; formal analysis, M.B.S. and A.S.-G.; writing-original draft preparation, M.B.S.; writing-review and editing, J.L.M., M.B.S. and A.S.-G.; supervision, J.L.M.; funding acquisition, J.L.M. All authors have read and agreed to the published version of the manuscript.

Funding: Work in our laboratory is supported by grants from the Instituto de Salud Carlos III (Spanish Network for Research on Infectious Diseases [RD16/0016/0011]), from the Spanish Ministry of Economy, Industry and Competitivity (BIO2017-83128-R) and from the Autonomous Community of Madrid (B2017/BMD-3691).

Institutional Review Board Statement: Not applicable.

Informed Consent Statement: Not applicable.

Data Availability Statement: Data sharing not applicable.

Conflicts of Interest: The authors declare no conflict of interest. The funders had no role in study design, data collection and interpretation, or the decision to submit the work for publication.

\section{References}

1. Govil, D.; Gupta, S.; Malhotra, A.; Kakar, P.N.; Arora, D.; Das, S.; Govil, P.; Prakash, O. Colistin and polymyxin B: A re-emergence. Indian J. Crit. Care Med. 2009, 13, 49-53. [CrossRef] [PubMed]

2. Li, J.; Nation, R.L.; Milne, R.W.; Turnidge, J.D.; Coulthard, K. Evaluation of colistin as an agent against multi-resistant Gramnegative bacteria. Int. J. Antimicrob. Agents 2005, 25, 11-25. [CrossRef] [PubMed]

3. Karaiskos, I.; Giamarellou, H. Multidrug-resistant and extensively drug-resistant Gram-negative pathogens: Current and emerging therapeutic approaches. Expert Opin. Pharmacother. 2014, 15, 1351-1370. [CrossRef] [PubMed]

4. Falagas, M.E.; Rafailidis, P.I.; Matthaiou, D.K. Resistance to polymyxins: Mechanisms, frequency and treatment options. Drug Resist. Update 2010, 13, 132-138. [CrossRef] [PubMed]

5. Bialvaei, A.Z.; Kafil, H.S. Colistin, mechanisms and prevalence of resistance. Curr. Med Res. Opin. 2015, 31, 707-721. [CrossRef] [PubMed]

6. Baron, S.; Hadjadj, L.; Rolain, J.-M.; Olaitan, A.O. Molecular mechanisms of polymyxin resistance: Knowns and unknowns. Int. J. Antimicrob. Agents 2016, 48, 583-591. [CrossRef] [PubMed]

7. Olaitan, A.O.; Morand, S.; Rolain, J.-M. Mechanisms of polymyxin resistance: Acquired and intrinsic resistance in bacteria. Front. Microbiol. 2014, 5, 643. [CrossRef]

8. $\quad$ Liu, Y.-Y.; Wang, Y.; Walsh, T.R.; Yi, L.-X.; Zhang, R.; Spencer, J.D.; Doi, Y.; Tian, G.; Dong, B.; Huang, X.; et al. Emergence of plasmid-mediated colistin resistance mechanism MCR-1 in animals and human beings in China: A microbiological and molecular biological study. Lancet Infect. Dis. 2016, 16, 161-168. [CrossRef]

9. Pragasam, A.K.; Shankar, C.; Veeraraghavan, B.; Biswas, I.; Nabarro, L.E.B.; Inbanathan, F.Y.; George, B.; Verghese, S. Molecular Mechanisms of Colistin Resistance in Klebsiella pneumoniae Causing Bacteremia from India-A First Report. Front. Microbiol. 2017, 7, 2135. [CrossRef]

10. Granata, G.; Petrosillo, N. Resistance to Colistin in Klebsiella pneumoniae: A 4.0 Strain? Infect. Dis. Rep. 2017, 9, 69-72. [CrossRef] 
11. Andrade, F.F.; Silva, D.; Rodrigues, A.; Pina-Vaz, C. Colistin Update on Its Mechanism of Action and Resistance, Present and Future Challenges. Microorganisms 2020, 8, 1716. [CrossRef] [PubMed]

12. Boucher, H.W.; Talbot, G.H.; Bradley, J.S.; Edwards, J.E.; Gilbert, D.; Rice, L.B.; Scheld, M.; Spellberg, B.; Bartlett, J. Bad bugs, no drugs: No ESKAPE! An update from the Infectious Diseases Society of America. Clinical infectious diseases. Infect. Dis. Soc. Am. 2009, 48, 1-12.

13. Cannatelli, A.; Di Pilato, V.; Giani, T.; Arena, F.; Ambretti, S.; Gaibani, P.; D'Andrea, M.M.; Rossolini, G.M. In VivoEvolution to Colistin Resistance by PmrB Sensor Kinase Mutation in KPC-Producing Klebsiella pneumoniae Is Associated with Low-Dosage Colistin Treatment. Antimicrob. Agents Chemother. 2014, 58, 4399-4403. [CrossRef] [PubMed]

14. Cheng, Y.-H.; Lin, T.-L.; Lin, Y.-T.; Wang, J.-T. Amino Acid Substitutions of CrrB Responsible for Resistance to Colistin through CrrC in Klebsiella pneumoniae. Antimicrob. Agents Chemother. 2016, 60, 3709-3716. [CrossRef] [PubMed]

15. Jayol, A.; Nordmann, P.; Brink, A.; Poirel, L. Heteroresistance to Colistin in Klebsiella pneumoniae Associated with Alterations in the PhoPQ Regulatory System. Antimicrob. Agents Chemother. 2015, 59, 2780-2784. [CrossRef]

16. Jayol, A.; Poirel, L.; Brink, A.; Villegas, M.-V.; Yilmaz, M.; Nordmann, P. Resistance to Colistin Associated with a Single Amino Acid Change in Protein PmrB among Klebsiella pneumoniae Isolates of Worldwide Origin. Antimicrob. Agents Chemother. 2014, 58, 4762-4766. [CrossRef] [PubMed]

17. Poirel, L.; Jayol, A.; Nordmann, P. Polymyxins: Antibacterial Activity, Susceptibility Testing, and Resistance Mechanisms Encoded by Plasmids or Chromosomes. Clin. Microbiol. Rev. 2017, 30, 557-596. [CrossRef]

18. Wright, M.S.; Suzuki, Y.; Jones, M.B.; Marshall, S.H.; Rudin, S.D.; Van Duin, D.; Kaye, K.; Jacobs, M.R.; Bonomo, R.A.; Adams, M.D. Genomic and Transcriptomic Analyses of Colistin-Resistant Clinical Isolates of Klebsiella pneumoniae Reveal Multiple Pathways of Resistance. Antimicrob. Agents Chemother. 2014, 59, 536-543. [CrossRef]

19. Moffatt, J.H.; Harper, M.; Harrison, P.; Hale, J.D.F.; Vinogradov, E.; Seemann, T.; Henry, R.; Crane, B.; Michael, F.S.; Cox, A.D.; et al. Colistin Resistance in Acinetobacter baumannii Is Mediated by Complete Loss of Lipopolysaccharide Production. Antimicrob. Agents Chemother. 2010, 54, 4971-4977. [CrossRef]

20. Cannatelli, A.; Giani, T.; D’Andrea, M.M.; Di Pilato, V.; Arena, F.; Conte, V.; Tryfinopoulou, K.; Vatopoulos, A.; Rossolini, G.M. MgrB Inactivation Is a Common Mechanism of Colistin Resistance in KPC-Producing Klebsiella pneumoniae of Clinical Origin. Antimicrob. Agents Chemother. 2014, 58, 5696-5703. [CrossRef]

21. Poirel, L.; Jayol, A.; Bontron, S.; Villegas, M.-V.; Ozdamar, M.; Türkoglu, S.; Nordmann, P. The mgrB gene as a key target for acquired resistance to colistin in Klebsiella pneumoniae. J. Antimicrob. Chemother. 2014, 70, 75-80. [CrossRef]

22. Campos, M.A.; Vargas, M.A.; Regueiro, V.; Llompart, C.M.; Albertí, S.; Bengoechea, J.A. Capsule Polysaccharide Mediates Bacterial Resistance to Antimicrobial Peptides. Infect. Immun. 2004, 72, 7107-7114. [CrossRef] [PubMed]

23. Padilla, E.; Llobet, E.; Doménech-Sánchez, A.; Martínez-Martínez, L.; Bengoechea, J.A.; Albertí, S. Klebsiella pneumoniae AcrAB Efflux Pump Contributes to Antimicrobial Resistance and Virulence. Antimicrob. Agents Chemother. 2009, 54, 177-183. [CrossRef] [PubMed]

24. Srinivasan, V.B.; Rajamohan, G. KpnEF, a New Member of the Klebsiella pneumoniae Cell Envelope Stress Response Regulon, Is an SMR-Type Efflux Pump Involved in Broad-Spectrum Antimicrobial Resistance. Antimicrob. Agents Chemother. 2013, 57, 4449-4462. [CrossRef] [PubMed]

25. Sanz-Garcia, F.; Hernando-Amado, S.; Martinez, J.L. Mutation-driven evolution of Pseudomonas aeruginosa in the presence of either ceftazidime or ceftazidime/avibactam. Antimicrob. Agents Chemother. 2018, 62, e01379-18. [CrossRef] [PubMed]

26. Sanz-García, F.; Sánchez, M.B.; Hernando-Amado, S.; Martínez, J.L. Evolutionary landscapes of Pseudomonas aeruginosa towards ribosome-targeting antibiotic resistance depend on selection strength. Int. J. Antimicrob. Agents 2020, 55, 105965. [CrossRef]

27. Hernando-Amado, S.; Sanz-García, F.; Martínez, J.L. Antibiotic Resistance Evolution Is Contingent on the Quorum-Sensing Response in Pseudomonas aeruginosa. Mol. Biol. Evol. 2019, 36, 2238-2251. [CrossRef]

28. Sanz-García, F.; Hernando-Amado, S.; Martínez, J.L. Mutational Evolution of Pseudomonas aeruginosa Resistance to RibosomeTargeting Antibiotics. Front. Genet. 2018, 9, 451. [CrossRef]

29. Blanco, P.; Corona, F.; Martínez, J.L. Involvement of the RND efflux pump transporter SmeH in the acquisition of resistance to ceftazidime in Stenotrophomonas maltophilia. Sci. Rep. 2019, 9, 1-14. [CrossRef]

30. Blanco, P.; Corona, F.; Martínez, J.L. Mechanisms and phenotypic consequences of acquisition of tigecycline resistance by Stenotrophomonas maltophilia. J. Antimicrob. Chemother. 2019, 74, 3221-3230. [CrossRef]

31. Nassif, X.; Sansonetti, P.J. Correlation of the virulence of Klebsiella pneumoniae K1 and K2 with the presence of a plasmid encoding aerobactin. Infect. Immun. 1986, 54, 603-608. [CrossRef] [PubMed]

32. Storey, D.; McNally, A.; Åstrand, M.; Sa-Pessoa Graca Santos, J.S.-P.G.; Rodriguez-Escudero, I.; Elmore, B.; Palacios, L.; Marshall, H.; Hobley, L.; Molina, M.; et al. Klebsiella pneumoniae type VI secretion system-mediated microbial competition is PhoPQ controlled and reactive oxygen species dependent. PLoS Pathog. 2020, 16, e1007969. [CrossRef] [PubMed]

33. Holt, K.E.; Wertheim, H.; Zadoks, R.N.; Baker, S.; Whitehouse, C.A.; Dance, D.; Jenney, A.; Connor, T.R.; Hsu, L.Y.; Severin, J.; et al. Genomic analysis of diversity, population structure, virulence, and antimicrobial resistance in Klebsiella pneumoniae, an urgent threat to public health. Proc. Natl. Acad. Sci. USA 2015, 112, E3574-E3581. [CrossRef] [PubMed]

34. Humphries, R.M.; Green, D.A.; Schuetz, A.N.; Bergman, Y.; Lewis, S.; Yee, R.; Stump, S.; Lopez, M.; Macesic, N.; Uhlemann, A.-C.; et al. Multicenter Evaluation of Colistin Broth Disk Elution and Colistin Agar Test: A Report from the Clinical and Laboratory Standards Institute. J. Clin. Microbiol. 2019, 57, e01269-19. [CrossRef] [PubMed] 
35. Martínez, J.L.; Coque, T.M.; Baquero, F. What is a resistance gene? Ranking risk in resistomes. Nat. Rev. Genet. 2015, 13, 116-123. [CrossRef]

36. Dafopoulou, K.; Zarkotou, O.; Dimitroulia, E.; Hadjichristodoulou, C.; Gennimata, V.; Pournaras, S.; Tsakris, A. Comparative Evaluation of Colistin Susceptibility Testing Methods among Carbapenem-Nonsusceptible Klebsiella pneumoniae and Acinetobacter baumannii Clinical Isolates. Antimicrob. Agents Chemother. 2015, 59, 4625-4630. [CrossRef]

37. Cingolani, P.; Patel, V.M.; Coon, M.; Nguyen, T.; Land, S.J.; Ruden, D.M.; Lu, X. Using Drosophila melanogaster as a Model for Genotoxic Chemical Mutational Studies with a New Program, SnpSift. Front. Genet. 2012, 3, 35. [CrossRef]

38. Hjort, K.; Nicoloff, H.; Andersson, D.I. Unstable tandem gene amplification generates heteroresistance (variation in resistance within a population) to colistin in Salmonella enterica. Mol. Microbiol. 2016, 102, 274-289. [CrossRef]

39. Xie, C.; Tammi, M.T. CNV-seq, a new method to detect copy number variation using high-throughput sequencing. BMC Bioinform. 2009, 10, 1-9.

40. Madeira, F.; Park, Y.M.; Lee, J.; Buso, N.; Gur, T.; Madhusoodanan, N.; Basutkar, P.; Tivey, A.R.N.; Potter, S.C.; Finn, R.D.; et al. The EMBL-EBI search and sequence analysis tools APIs in 2019. Nucleic Acids Res. 2019, 47, W636-W641. [CrossRef]

41. Pontarollo, R.; Rioux, C.R.; Potter, A. Cloning and characterization of bacteriophage-like DNA from Haemophilus somnus homologous to phages P2 and HP1. J. Bacteriol. 1997, 179, 1872-1879. [CrossRef] [PubMed]

42. Weaver, L.; Matthews, B. Structure of bacteriophage T4 lysozyme refined at 1.7 A resolution. J. Mol. Biol. 1987, 193, 189-199. [CrossRef]

43. Wu, B.; Gong, J.; Liu, L.; Li, T.; Wei, T.; Bai, Z. Evolution of prokaryotic homologues of the eukaryotic SEFIR protein domain. Gene 2012, 492, 160-166. [CrossRef]

44. Hsu, M.Y.; Inouye, M.; Inouye, S. Retron for the 67-base multicopy single-stranded DNA from Escherichia coli: A potential transposable element encoding both reverse transcriptase and Dam methylase functions. Proc. Natl. Acad. Sci. USA 1990, 87, 9454-9458. [CrossRef] [PubMed]

45. Dodd, I.B.; Egan, J.B. The Escherichia coli retrons Ec67 and Ec86 replace DNA between the cos site and a transcription terminator of a 186-related prophage. Virology 1996, 219, 115-124. [CrossRef]

46. McClelland, M.; Sanderson, K.E.; Spieth, J.; Clifton, S.W.; Latreille, P.; Courtney, L.; Porwollik, S.; Ali, J.; Dante, M.; Du, F.; et al. Complete genome sequence of Salmonella enterica serovar Typhimurium LT2. Nat. Cell Biol. 2001, 413, 852-856. [CrossRef]

47. Munoz-Price, L.S.; Poirel, L.; Bonomo, R.A.; Schwaber, M.J.; Daikos, G.L.; Cormican, M.; Cornaglia, G.; Garau, J.; Gniadkowski, M.; Hayden, M.K.; et al. Clinical epidemiology of the global expansion of Klebsiella pneumoniae carbapenemases. Lancet Infect. Dis. 2013, 13, 785-796. [CrossRef]

48. Torres-Barceló, C. The disparate effects of bacteriophages on antibiotic-resistant bacteria. Emerg. Microbes Infect. 2018, 7, 1-12. [CrossRef]

49. Wang, X.; Kim, Y.; Ma, Q.; Hong, S.H.; Pokusaeva, K.; Sturino, J.M.; Wood, T.K. Cryptic prophages help bacteria cope with adverse environments. Nat. Commun. 2010, 1, 147. [CrossRef]

50. Sandegren, L.; Andersson, D.I. Bacterial gene amplification: Implications for the evolution of antibiotic resistance. Nat. Rev. Genet. 2009, 7, 578-588. [CrossRef]

51. Nassif, X.; Fournier, J.M.; Arondel, J.; Sansonetti, P.J. Mucoid phenotype of Klebsiella pneumoniae is a plasmid-encoded virulence factor. Infect. Immun. 1989, 57, 546-552. [CrossRef] [PubMed]

52. Tomas, A.; Lery, L.; Regueiro, V.; Perez-Gutierrez, C.; Martinez, V.; Moranta, D.; Llobet, E.; Gonzalez-Nicolau, M.; Insua, J.L.; Tomas, J.M.; et al. Functional Genomic Screen Identifies Klebsiella pneumoniae Factors Implicated in Blocking Nuclear Factor kappaB (NF-kappaB) Signaling. J. Biol. Chem. 2015, 290, 16678-16697. [CrossRef] [PubMed]

53. Atlas, R. Handbook of Microbiological Media; CRC Press: Boca Raton, FL, USA, 1993.

54. Satlin, M.J.; Lewis, J.S.; Weinstein, M.P.; Patel, J.; Humphries, R.M.; Kahlmeter, G.; Giske, C.G.; Turnidge, J. Clinical and Laboratory Standards Institute and European Committee on Antimicrobial Susceptibility Testing Position Statements on Polymyxin B and Colistin Clinical Breakpoints. Clin. Infect. Dis. 2020, 71, e523-e529. [CrossRef] [PubMed]

55. Llobet, E.; Campos, M.A.; Giménez, P.; Moranta, D.; Bengoechea, J.A. Analysis of the Networks Controlling the AntimicrobialPeptide-Dependent Induction of Klebsiella pneumoniae Virulence Factors. Infect. Immun. 2011, 79, 3718-3732. [CrossRef] [PubMed]

56. Langmead, B.; Salzberg, S.L. Fast gapped-read alignment with Bowtie 2. Nat. Methods 2012, 9, 357-359. [CrossRef] [PubMed]

57. Li, H. A statistical framework for SNP calling, mutation discovery, association mapping and population genetical parameter estimation from sequencing data. Bioinformatics 2011, 27, 2987-2993. [CrossRef]

58. Li, H.; Handsaker, B.; Wysoker, A.; Fennell, T.; Ruan, J.; Homer, N.; Marth, G.; Abecasis, G.; Durbin, R.; Project, G.; et al. The Sequence Alignment/Map format and SAMtools. Bioinformatics 2009, 25, 2078-2079. [CrossRef]

59. Cingolani, P.; Platts, A.; Wang, L.L.; Coon, M.; Nguyen, T.; Wang, L.; Land, S.J.; Lu, X.; Ruden, D.M. A program for annotating and predicting the effects of single nucleotide polymorphisms, SnpEff: SNPs in the genome of Drosophila melanogaster strain w1118; iso-2; iso-3. Fly 2012, 6, 80-92. [CrossRef]

60. Quinlan, A.; Hall, I.M. BEDTools: A flexible suite of utilities for comparing genomic features. Bioinformatics 2010, 26, 841-842. [CrossRef]

61. Choi, Y.; Chan, A. PROVEAN web server: A tool to predict the functional effect of amino acid substitutions and indels. Bioinformatics 2015, 31, 2745-2747. [CrossRef] 
62. Zhou, Y.; Liang, Y.; Lynch, K.H.; Dennis, J.J.; Wishart, D.S. PHAST: A Fast Phage Search Tool. Nucleic Acids Res. 2011, 39, W347-W352. [CrossRef] [PubMed]

63. Arndt, D.; Grant, J.R.; Marcu, A.; Sajed, T.; Pon, A.; Liang, Y.; Wishart, D.S. PHASTER: A better, faster version of the PHAST phage search tool. Nucleic Acids Res. 2016, 44, W16-W21. [CrossRef] [PubMed]

64. Livak, K.J.; Schmittgen, T.D. Analysis of relative gene expression data using real-time quantitative PCR and the 2-DDCT Method. Methods 2001, 25, 402-408. [CrossRef] [PubMed] 